\title{
Content Analysis of Faatee Blessing in Case of Arsi Oromo Peoples
}

\author{
Temam Kedir Iteya \\ Collage of Social Science and Humanities, Madda Walabu University, Robe Bale, Ethiopia
}

\begin{abstract}
The major Objective of this study was to analyis the content of Eebba Faatee (Fate Blessing) in case of Oromia regional state Westi Arsi Zone. To achieve the paper objectives, qualitative research approach was employed, for it can guide the researcher to collect qualitative data. From the West Arsi Zone, 4 districts were selected purposively. In this manner, 5 elders were selected from each District by using snowball and Purposive sampling technique. Totally, 20 elders were involved in the study from which the data was collected though semistructured interview and focus group discussion and observation. After that the collected data were carefully transcribed, and analyzed critically according to their aspects. Thus, the result of the study shows that Eebba Faatee (Fate Blessing) has different Contents. From those contents, Eebba Faatee which was said to beg Creator and Creation, Eebba Faatee which was said to wish someone's strength and to be clone, eebba faatee which was said tokeep their unity and to be Brave (Legend), Eebba Faatee which was said to wish peace, and Eebba Faatee which was said to advise someone.
\end{abstract}

Keywords: Content, Eebba Faatee, Oromo, West Arsi

DOI: $10.7176 / \mathrm{JLLL} / 76-01$

Publication date: February $28^{\text {th }} 2021$

\section{Introduction}

Oromo people have its own Culture, history, identity, custom and etc. By using Oral literature, they have been transferring this lore from generations to generation. According to Fedhasaa Taaddasaa (2013), Misgaanuu (2011) and Geetaachoon (2008:114) Oral literature is a type of literature which tranismit culture, history and identity of one society from generation to generation orally. According to Biraanuu (1999:11) and Fennegan (1970) Oral literature has many types. Those are proverbs or saying, nattarion, songs, riddles, tune, imprecation, blessing, insult and etc. Oral literature is an expiriance of one society. This means oral literature is the reflection of the life of one society. The Oral literature of Oromo people is very wide and unreachable. It is the wealth of Oromo society. According to Worquu Dachaasaa (2001) Oral literature Intangiable heritages. It is preservation is concerned with protection of folk traditions and those who are transimetters, having the fact that each people have a right to its own lulture'. Among Afro-Eshiatic languages Afaan Oromoo is the family of Kush. This language has more than 30 million speakers and the third most speakers in Africa. According to http;//en.wikipedia.Org/wiki/Oromo people world cultures; Costa Rica to Georgia 2000-2007, 2008)

Afan Oromo has more than thirty million speakers. Afan Oromo is the third most widely Spoken language in Africa after Arabic and Hausa. It is the second most widely spoken indigenous language In Africa south of the Sahara. Inispite of attempts by Ethiopian regimes to destroy the Afan Oromo Language, it has continued to exist and flourish in nasal areas. Until recently Oromos were derived the right to develop their language, literature and alphabet. For almost a centuary, it was a crime to write in this language.

According to the above idea, Afan Oromo has more than 30 million speakers and also the third most speakers' language among African Languages next to Arabic and Hawusa. Additionally, Afan Oromo is among languages which founded in south Sahara and the most known and great language. But, because of the past political influence in Ethiopia on Oromo people, this great and known language didn't investigate and developed.

Alamaayyoo(2007:1) said ,"Untill recently Oromo peoples are one of the Ethiopian people whose culture and history is not thoroughly studied. The main re ason for this is the fact that politically stubmerged people in Ethiopia in historical studies." According to the above mentioned idea, among the Ethiopian peoples those who are their culture and language were not studied well is Oromo People. The reason why the culture, history and language of Oromo people did not studied was the influence of Amara people and the past government of neftegna system in Ethiopia. Language is the symbol of people for those who speaks that language. And also language carried out History and culture of one society and transfer from generation to generation. So language and culture can not seen as defferent things. Because, to describe one society, the culture, history and language are very imortant elements. According to Misgaanuu (2012:62) "to develop the culture of one society the language has very important role. This shows the relationship between language and culture" culture is the reflection of the life of one society. The key element to distinguish one society from the others society is Culture. The example of those cultures are the culture of respecting each other, dressing culture, food culture, culture of marriage, culture of helping each other, culture of ritual ceremony, culture of song (art), custom and etc. 
According to 'Oxford Advanced Dictioary',"culture is the customs and beliefs, art way of life and social organization of a particular country or group."

According to this idea, this the same groups have been transferring those culture ftom generations to generation. Oral literature transfer culture, history and the identity of one society from generations to generation. Oral literature has different types. Those are, proverbs or saying, nattarion, songs, riddles, tune, imprecation, blessing, insult and etc. to support this idea, Dandes,(1965:3)”'The form of folklores are;myths ,legends, folk tales ,jokes ,proverbs ,riddles ,chants ,charms ,blessings, curses ,oaths ,insults ,retorts ,taunts ,teases ,toasts ,tou ngue twisters, greeting and etc. so amond those oral culture this paper analysis about the contents of EEbba Faatee (Faatee Blessing) of West Arsi Oromo.

Oromo has two sons. Those are Borana and Barentu. Barentu has also many sons. Those are Humbaana, Arsii, Wollo, Karrayyuu, Arfan Qallo, Ituu and Marawaa BATO (1998) fi Muhaammad (2004). Most of Bareentus sons are lives in East Oromia including West Arsi.

The words Arsii, Arsummaa, Arsoomaa, Arsichaa and Arsittii, they all describe the one who are from Arsi. The word "Arsii" is respected and intense word near Arsii Oromos. Muhaammad (2004:54) said. . "Arsoma is the name of Roots of blood, unity and oath (Promise) of Arsi Oromo. It is the message of great grandfather for the son of Arsi (Sikko and Mando). Generally, near Arsi Oromo the word "Arsii" is the name of Respect, love and Brotherhood.

According to Husseen Badhaasoo (2000:6) Arsewas women (dubarti'i). She was the wife of Ambato. Ambato is the son of Dooyyoo. Daayyoo was the son of Suphee. Suphe was the son Seeruu.

According to Muhaammad, (2004:54) "by saying Sikkoo-Mando, Arsi has two sons. Those are Sikko and Mando. Sikko has five sons. Mando has seven sons". The sons of Mando are Raayyaa, Kajawa, Hawaxxuu, Waanama, Utaa, Waayyuu and Biiltuu/Arroojjii BATO (1998), Husseen (2000) fi Muhaammad (2004). The sons of Mando are lives in West Arsi Zones. This paper also investigated on those Mando sons.

\section{Review of Literature}

\subsection{Definition of Folklore}

Many scholars havegiven many definitions for Folklore. Ben Amos (1972:3) "Folklor is a verbal art, UN recorded mentifacts and literature orally transmitted." According to Dandes (2007:15). "Folklore is aword very much like culture it represents a tremendous spectrum of human expression that can be studied in a number of reasons."

\subsection{Meanings of Oral literature}

Oral literature is the types of literature which transmited orally from generations to generation. Sims (2005:13) said,

Verbal folklore includes and kind of lore involving words, wether set or music, organized in chronological, storyform, or simpley labeling an acti vity or expressing a belief in a word or phrase. Some of the most recognizable forms of verbal core studied by folklorists are folk song, myths, and folk tales.

In Oromo Oral literature it is difficult to desied when and by whom it was started. This characteristic of Oral literature shows that Oral literature is the lore of the society.

\subsection{The Types of Oral literature}

According to Dandes (2007) there are three main types of oral literature. Those are Oral Poem, Narrations and witsism.

\subsection{Oral Poem}

Oral poem is a types of Oral literature which is poeted by the society those who cannot read and write and transmitted from generations to generation. The concepts of Oral poem are very complex. And also Oral Poem transmitted orally from generation to generation. Finnegan (1976:17).

\subsection{Faatee Blessing (Eebba Faatee)}

Before we discuss about Blessing we have to say something about Religion. Because, for the habitation of blessing, the presence of religion is mandatory. Many scholars say about blessing as follows. Oring (1986) says Religious folklore is alense through wich religious experience as well as non-religious experience can be investigated The Free Encyclopedia also says Ablessing is the infusion of some thing with holiness, divine will, or ones hope or approval. 


\section{Methodology}

\subsection{Research Design}

Relevant data is important for any research to achieve research Objectives and to answer the research questions. The research is designed a qualitative approach. To collect the necessary and relevant data the researcher was used various methods like interview, group discussion and observation.

\subsection{Data Sources}

Both primary and secondary data are utilized in this research. The primary sources of data were Oromo community living West Arsi in the Shashemene District, Kofale Districs, Arsi Nagele District and Kokosa Districs of the Oromia National Regional State who have different societal status (men, women and the youth and etc).

Whereas, the secondary sources were included official documents and related literatures to enrich the primary data. The information from West Arsi Zoneadministrative personnel and other organizations helped me in this study.

\subsection{Sampling and Sampling Techniques}

Participants were selected through snowball sampling technique and Puposive sampling thechnique. In order to arrive at an in-depth investigation of the Content of Faatee blessing in research areas, representative sample or selection of peoples who are represent the society by their knowledge and skills of Faatee blessing and about the cultures, tradition and about the society were taken from the target population with employing the sampling techniques, preferred for this study. While collecting data, first the researcher asked experts of West Arsi Zone Culture and Tourism Office to inform researcher the locations of the well known elders. Based on that information the researcher selected key informants. Accordingly, researcher selected 20 participants 5 from Kofale District, 5 Shashemene district, 5 from Arsi Nagele District and5 from Kokosa Districs. So, that all the necessary data sources were contacted for the qualitative.

\subsection{Methods of Data Collection}

This research used both primary and secondary sources. With regards to collecting the primary data, interviews (structured and semi-structured interviews) and group discussions were used depending on the type of information resercher intended to gather. And observation methods were used for collecting the data on specific issues and research targets the attitude and perception of the target and the existence of supplementary method such as systematic interview was utilized. Ithe researcher prepared a list of questions for all interviewers. However, more questions was asked depending on the rapport between researcher and interviewees. All interviews was conducted in Afan Oromo because it is the local language, researcher and informants speak and did not used the service of translators which is audio taped and translated and transcribed as necessary.

\subsection{Methods of Data Analysis}

In this study, qualitative data analysis methods were employed. The researcher conducted document analysis to get the necessary and reliable information by reviewing the available documents and tried to make a link between different variables regarding to the content Faatee blessing. This method then helpe researcher to cross check and triangulate the data obtained through interview and focus group discussions and observation. So, the qualitative research method is the most selected method that is used in the process of conducting this study. The method is preferred in its ease for analyzing and interpreting non quantitative data that are to be gathered on cultural.

\section{Discussion and Findings of this paper}

\subsection{Faatee blessing for begging of Creator and creation}

West Arsi Oromo People use Faatee blessing for begging their creator and God's creation. "Uumaa" means the creation of God such as Earth, sky, cow, human being and all living things and non living things. "Uumamaa"means the creator. So West Arsi Oromo People benedicate Creator and God's creation by using Fate Blessing. When they want to beg their Creator and Creation they use the following Fate Blessing.

Faatee waandhi sii dhagahi Let creator accept your pray

Lafti sii dhagahi. let the Earth accept your pray

Dhibaayyuun sii dhagahi. let Full things accept your pray

Gadaan sii dhagahi................ let Gada (Oromo democracy) accept your pray

Gadamoojjiin sii dhagahi. ... let elders accept your pray

Kaakka sii dhagahi............. let Kaka (The name of mountain) accept your pray

Arsi Oromo People use this Faatee Blessing to explain the power of Creator. And also it is culture of Arsi Oromo people to beg their creator by using God's creation like Earch, Sky, River, Mountain and etc. In the 
above Oral Poem, Waaqaa is Creator. But, Lafa (Earth), dhibaayyuu (The full things), gadaa (Oromo Democratic system), gadamoojjii (Elders) and Kaakkaa (The Mountain called Kaakkaa) are Creation. So they beg their creator and they beg their creator by using God's Creation.

\subsection{Fate Blessing to pray for Growth, Clone and strength of some body}

Oromo People are very wide. And also very strong and cloned people. West Arsi Oromo People cloned of human being and animals and living in very wide area. To clone and to be strong they bless each other by using Fate blessing as follows.

Barii sii deebis. let the creator wake up you early

Barakata sii deebis. ... let the creator develop your entire product

Warra boruu si godhi let the creator make you the man of tomorrow

Warra horu si godhi let the creator make you clone

Durduuraa waggaa maraa itti si deebis................. Let the creator make you to live year to year

Muka raagaa si godhi. let the creator make you the tree of divination

Nama waaqaa si godhi......................... let he creator make you the man of God

Nama falfalan si godhi........................... let the creator make you the magic man

Nama dadhaban si godhi............................let the creator maku you the man

every body exhausted you

Horaa gabbadhaa. ... let you clone and develop

Bonaa ganna lalisaa.............................let you grow through summer and winter

Coqorsa ta'aa.... let creator make you Grass root

Lafa uwwisaa... let the creator make you clone and cover the earth

Duraa duubatti ifaa. let you future and your past be bright

The above Faate blessing explains the wishing of growth, clone and strength of some body. They says Fate blessing to beg God to make their day good. Most of West Arsi Oromo peoples are farmer and conjugation. So the pray to entire product. Additionally, according to West Arsi Oromo peoples, they have to have many childrens to be said wealthy man. So they say Fatee blessing to be more clone. Waabee gannaa si godhi. Let the creator make you Wabe

River of the summer let the creator make you the like honey

sweet

Rasaa dammaa si godhi.

Ejersa gaaraa si godhi Let the creator make you strong tree on the Mountain

the

Kan hinbuqqaane si godhi Let the creator make you the one who are not disappeared or removed

The above Faatee blessing said to beg the creator be strong, sweet and wide. They pray to God by using the God's creation like River, Honey, and Mountain. What we have to know is , they didn't beg the creation. By using the creation they beg their God's. As we know river goes very far and wide. So they said this Faatee blessing beg their creator to make them very wide clan and long live society. And also they use honey to bless each other. Honey is very sweet favorite food for Oromo people. So they pray for their speech to be sweet like honey. In addition they also use Mountain to beg their creator. Mountain is very robust and no one can destroy it easly. So they Says Faatee blessing to be strong like Mountain. 


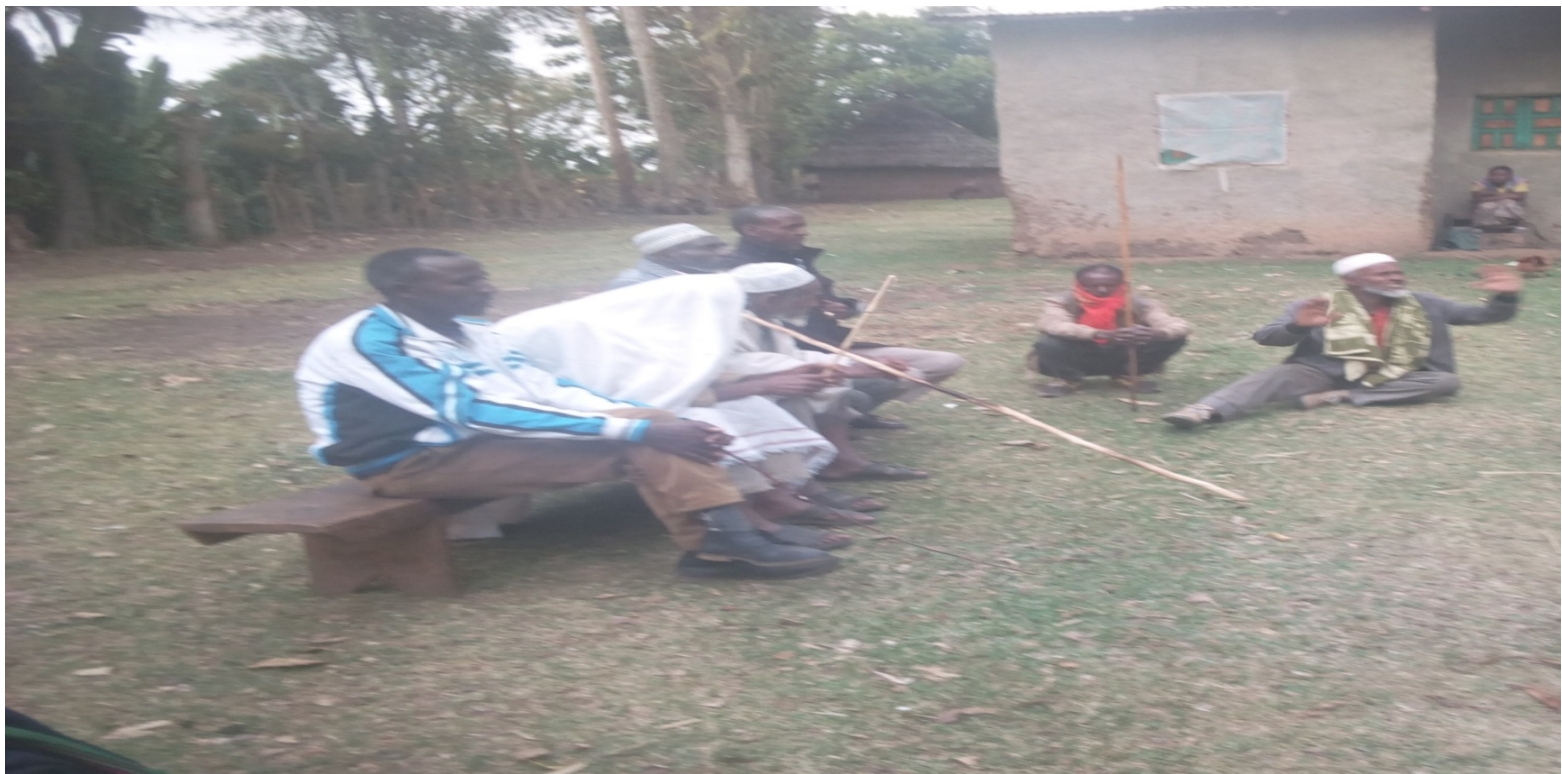

\section{Image one. When the informants are interviewing}

\subsection{Fate Blessing to pray for Unity and Bravery}

\begin{tabular}{|c|c|}
\hline adabi si galchi....... & et the creator enter vol \\
\hline Gadaa si hilluuqsis.. & let the creator pass you through Gada \\
\hline & creator return your war at home \\
\hline Mana qaqaatti si bulchi. & ..let the creator govern you by the ancient \\
\hline Oromo & \\
\hline a diinaa buqqis... & $\begin{array}{l}\ldots . \text { let the creator } g \\
\text { Pile of the } \mathrm{e}\end{array}$ \\
\hline ardaan si aasis ...... & ..let the creator make you to fight by your horse \\
\hline $\begin{array}{l}\text { Lafoo si aasis.... } \\
\text { by }\end{array}$ & $\begin{array}{c}\text {.... let the creator give you the ability to fight } \\
\text { infanry }\end{array}$ \\
\hline $\begin{array}{l}\text { Warra lallabaa si godhi. } \\
\text { every }\end{array}$ & $\begin{array}{l}\text {...let the creator make you the one whose } \\
\text { body preach you }\end{array}$ \\
\hline $\begin{array}{l}\text { Mala si beeksisi....... } \\
\text { all }\end{array}$ & $\begin{array}{l}\text {......let the creator show you the mechanis } \\
\text { things }\end{array}$ \\
\hline
\end{tabular}

Oromo people beg and remember their God every time and minutes. They prepared them selves to attach their enemies. To attach their enemies, they work on their unities every day. So to keep their environment and their society they have to have unity and be brave. To have unity and be brave they beg their God by using Faatee blessing. Near west Arsi Oromo "Gadab "is very know and blessed land. Whichi is very comfortable for rearing their cattles and childrens. It is very green area and wide. At winter time every Oromo's whose live in the west arsi zone immigrate to Gadab for their cattles. Because, Gadab had grass and every thing always. That is the reason why west Arsi Oromo people says "let the creator enter you to Gadab". Oromo Peoples are the people who created Gada system and contributed to the world. Accordingly they wish for every body to pass though Gada cycle.

\subsection{Fate Blessing to pray for Peace}

Peace is very important for our world and specifically for Oromo people. For this reason, to secure peace for them and others, West Arsi Oromo people use Faatee blessing as follows.

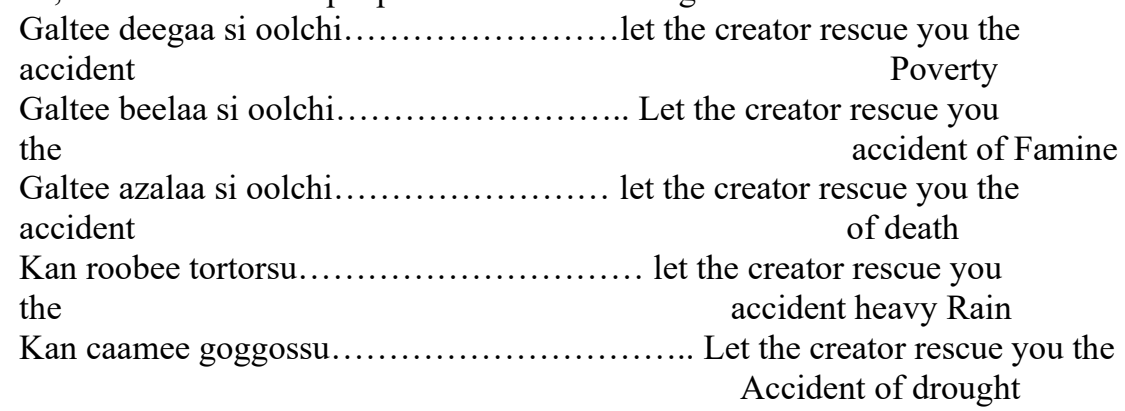


Faate blessing also said to wish peace for them selves and for others. They pray to the creator as to rescue them the accident poverty. In addition they beg the creator rescue them and others from accident of famine. Oromo people of West Arsi zone also beg their creator to rescue the selves from accident heavy rain and accident of drought. Generally Oromo people of west Arsi zone bless Faatee blessing on different stages and ritual ceremonies to wish peace for them and for people of the world.

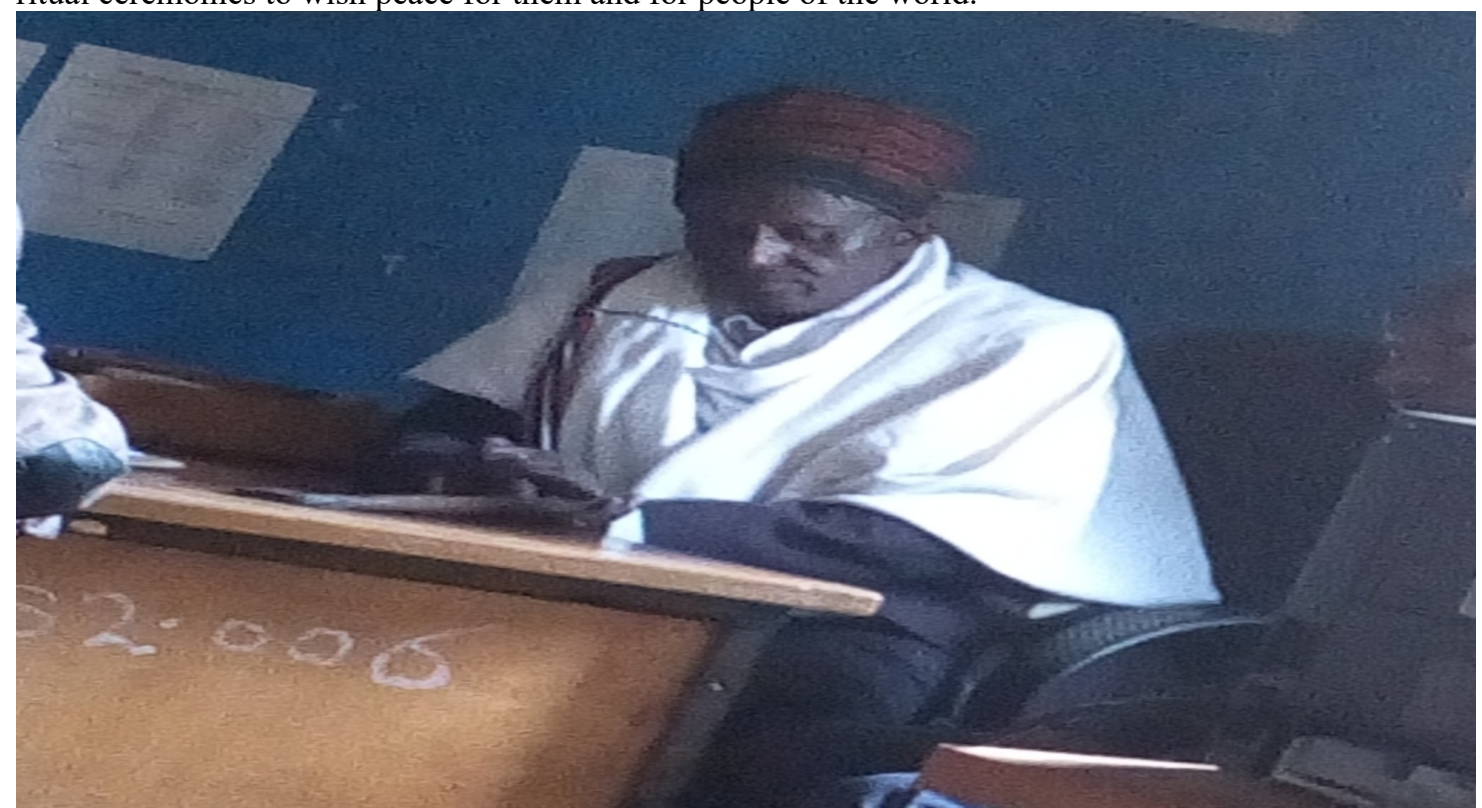

Picture three. The Abba Gada who says Faate Blessing on different stages or ritual ceremony.

\section{Conclusion}

Faatee blessing is very know and unique around Arsi Oromo people. This type of Oral literature is said or blessed by elders or by Abba Gadas. Elders and Abba Gadas say this blessing on different stages like ritual ceremonies. This customs of blessing performed at the end or closing of the different ceremony or stages. Arsi Oromo People use this Faatee Blessing to explain the power of Creator. And also it is culture of Arsi Oromo people to beg their creator by using God's creation like Earch, Sky, River, Mountain and etc. additionally, by using Faate blessing Arso Oromo people explains the wishing of growth, clone and strength of somebody. Plus, pray for Unity and Bravery. Likewise, they use Fate Blessing to pray for their Peace and for others. And certainly no one was allowed to talk and do another work during Faatee blessing.

The youths also often participate on different stages where Faatee blessing is said on, the learn about society, culture, significant relationships, values and traditions. The youth learned this Faatee blessing at different stages and ceremonies from eldersand thie families. For instance, they grew older and spent more time with elders and participated in different stages and they started to bless Faatee blessing.

\section{Referances}

Alamaayyoo Hayilee. (2007). Sirna Gadaa Siyaasa Oromoo Tuulamaa: Finfinnee. Biraaninnaa Salaam Interpiraayiz.

BATO. (1998). Seenaa Oromoo Hanga Jaarraa 16ffaa. Finfinnee.

Ben-Amos, Dan. (1972). Toward a Deffinition of Folklore in Context: In Paredes and Bauman.

C.R.Kothari. (1990). Research Methodology. Methods and Techiniques. New Age International (P) Limited Publishers.

Dandes, Allan. (1965). the Study of Folklore: Engle Wood Cliff, NJ Prentice Hall.

. (2007), the Meaning of Folklore: Uttah State University Press Logan, Uttah.

Finnegan Ruth. (1970). Oral Literature in Africa. Oxford: Clarendon Press.

Davide White, Hafiz T.A.Khan, Jhon Adams and Robert Raeside. (2007). Research Methods for Graduate Business and Social Science Students. New Delhi.

Husseen Badhaasoo. (2000). Seera Fuudhaafi Heeruma Oromoo Arsii: Finfinnee.

Jaarraa W.Bfi W.B Yaadatee. (2008). Bantuu Haaraa: Caaslugaafi Ogbarruu Afaan Oromoo. Finfinnee.

Maammoo Gadaa. (2002).Duudhaa. Finfinnee.

Malaakinee Mangistuu. (2006). Fundamentals of Literature. Addis Ababa University Press.

Maria Leach. (1996). Journal of Folklore Research: Indiana University Press.

Martha, C. Sims. (2005). Living Folklore: An Introduction to the Study of People and Their Traditions. Uttah 
State University Press.

Misgaanuu Gulummaa. (2012). Yandoo: Ogummaafi Ogwalaloo Oromoo. Finfinnee Oromiyaa.

Muhaammad Sayid Abdulrahmaan. (2004). Seenaa Qabsoo Oromootaa. Finfinnee.

Okpewho. (1992). African Oral Lterature. Nairobi.

Oring. E. (1986). Folk Groups and Folk Geners: An Introduction. Long Man AtlantaUniversity press.

Punch, F. (1998). Introduction to Social Research. New Delhi: SAGE. Publications Indian Pvt Ltd

Richard M. Dorson. (1972). Folklore and Folk Life: An Introduction. The University Of Chicago Press. Chicago and London.

The Free Encyclopedia: Galmee jechoota Afaan Ingliizii

Free Online Dictionary: Galmee jechoota Afaan Ingliizii 